\title{
Kedudukan Hukum Corporate Social Responsibility pada BUMD berdasar Undang-Undang RI Nomor 40 Tahun 2007
}

\author{
Muchamad Taufiq \\ Program Studi Akuntansi, STIE Widya Gama Lumajang \\ muchamadtaufiqmh@gmail.com
}

\begin{abstract}
Abstrak
Penelitian ini bertujuan untuk mengkaji, menganalisis, menemukan makna filosofis Corporate Social Responsibility (CSR). Disisi lain penelitian ini bertujuan menemukan, menjelaskan kedudukan hukum Corporate Social Responsibility pada Badan Usaha Milik Daerah (BUMD). Undang-Undang Nomor 40 Tahun 2007 Tentang Perseroan Terbatas (UUPT) telah memberikan guidance bahwa terdapat tanggung jawab sosial perusahaan terhadap lingkungannya. Namun UUPT tersebut belum memuat sanksi yang jelas sehingga sifatnya tidak imperative serta obyek sasarannya adalah perusahaan berbentuk PT yang bergerak dibidang pertambangan. Corporate Social Responsibility yang diartikan sebagai tanggung jawab sosial dan lingkungan merupakan kewajiban perseroan yang dianggarkan dan diperhitungkan sebagai biaya perseroan yang pelaksanaannya dilakukan dengan memperhatikan kepatutan dan kewajaran. Metode penelitian yang digunakan adalah pendekatan yuridis normatif Obyek penelitiannya adalah semua peraturan perundangundangan yang terkait dengan Corporate Social Responsibility dan BUMD. Teknik pengumpulan data dalam penelitian ini, dilakukan dengan cara Library reseach. Selanjutnya penelitian ini diharapkan dapat memberikan kontribusi dalam pengembangan kajian ilmu hukum khususnya hukum bisnis sehingga dapat menjadi acuan penelitian sejenis dan penelitian lanjutan.
\end{abstract}

Kata Kunci : Kedudukan Hukum, CSR, dan BUMD.

\begin{abstract}
This study aims to study, analyze, find the philosophical meaning of Corporate Social Responsibility (CSR). On the other hand this study aims to find out, explain the legal position of Corporate Social Responsibility in Regionally Owned Enterprises (BUMD). Law Number 40 of 2007 concerning Limited Liability Companies (UUPT) has provided guidance that there is a corporate social responsibility to its environment. However, the UUPT does not contain clear sanctions so that its nature is not imperative and the target object is a company in the form of PT which is engaged in mining. Corporate Social Responsibility, which is defined as social and environmental responsibility, is a corporate obligation that is budgeted and counted as a company expense which is carried out with due regard to propriety and fairness. The research method used is the normative juridical approach. The object of the research is all the laws and regulations related to Corporate Social Responsibility and BUMD. Data collection techniques in this study, carried out by means of Library reseach. Furthermore, this research is expected to contribute to the development of the study of legal science, especially business law so that it can be a reference for similar research and further research.
\end{abstract}

Keywords: Legal Position, CSR, and BUMD. 


\section{PENDAHULUAN}

Undang-Undang Republik Indonesia Nomor 40 Tahun 2007 tentang Perseroan Terbatas (UUPT) merupakan dasar implementasi Corporate Social Responsibility (CSR) bagi dunia perusahaan di Indoensia. Berdasarkan Undang-Undang Dasar Negara Republik Indonesia Tahun 1945 (UUD NRI 1945) Pasal 33 mengamanatkan bahwa perekonomian Indonesia disusun berdasar atas azas kekeluargaan. Makna demokrasi ekonomi dalam Perekonomian nasional diselenggarakan dengan prinsip kebersamaan, efisiensi berkeadilan, berkelanjutan, berwawasan lingkungan, kemandirian, serta dengan menjaga keseimbangan kemajuan dan kesatuan ekonomi nasional, perlu didukung oleh kelembagaan perekonomian yang kokoh dalam rangka mewujudkan kesejahteraan masyarakat.

Perseroan Terbatas (PT) sebagai badan hukum di Indonesia merupakan salah satu pilar pembangunan perekonomian nasional perlu didukung berbagai regulasi untuk lebih memacu pembangunan nasional yang disusun sebagai usaha bersama berdasar atas asas kekeluargaan. Undang-Undang (UU) RI Nomor 40 Tahun 2007 tentang Perseroan Terbatas merupakan jawaban atas kelemahan UU RI Nomor 1 Tahun 1995 yang dipandang sudah tidak sesuai lagi dengan perkembangan hukum dan kebutuhan masyarakat sehingga perlu diganti dengan undang-undang yang baru. Dunia bisnis saat ini berkembang pesat, sementara persaingan meningkat tajam dan ketat. Perkembangan perusahaan berkorelasi pada tingkat kesenjangan sosial dan kerusakan lingkungan. Kesenjangan sosial ditunjukkan dengan bersinggungannya antara kepentingan perusahaan untuk berekspansi dengan hak-hak masyarakat yang harus dilindungi.

Disisi lain, semakin tingginya aktifitas perusahaan sehingga tidak terkendali terhadap pemanfaatan berbagai sumber daya untuk meningkatkan laba perusahaan mengakibatkan berkurangnya fungsi lingkungan. Selain pihak yang terkait langsung dengan perusahaan, masyarakat dan lingkungan sekitar perusahaan pun merasakan dampak yang ditimbulkan oleh aktifitas operasional perusahaan. Kondisi tarik ulur terhadap kepentingan lingkungan, menyebabkan perusahaan tidak hanya bertanggung jawab kepada para stakeholder, tetapi juga kepada pihak-pihak yang memiliki kepentingan dengan perusahaan, seperti pelanggan, pemilik atau investor, supplier, komunitas dan juga pesaing (Rika dan Islahihudi, 2008 dalam Gusti Ayu Made Ervina Rosiana dan Gede Juliarsa, 2013).

Dunia bisnis dewasa ini, salah satu faktor keberhasilannya ditentukan oleh kontribusinya terhadap kesejahteraan masyarakat umum. Suatu entitas dalam menjalankan usahanya tidak terlepas dari masyarakat dan lingkungan sekitarnya, sehingga menciptakan hubungan timbal balik antara masyarakat dan perusahaan. Perusahaan membutuhkan suatu respon yang positif dari masyarakat yang diperoleh melalui apa yang dilakukan oleh perusahaan kepada para stakeholder, termasuk masyarakat dan lingkungan sekitar (Kamil dan Antonius, 2012).

Corporate Social Responsibility (CSR) adalah suatu bentuk tanggung jawab yang dilakukan perusahaan terhadap lingkungan sekitarnya. Tanggung jawab sosial perusahaan merupakan upaya perusahaan dalam memperbaiki kesenjangan sosial dan kerusakan-kerusakan lingkungan yang terjadi akibat dari aktifitas operasional perusahaan. Semakin tinggi penerapan tanggung jawab sosial yang dilakukan perusahaan terhadap lingkungannya, akan meningkatkan image perusahaan di masyarakat. kualitas pelaksanaan CSR dapat meningkatkan citra perusahaan. Dunia investasi modern membuktikan bahwa investor lebih berminat pada perusahaan yang memiliki citra baik di masyarakat. Hal mana menunjukkan bahwa semakin baik citra perusahaan, maka dapat dipastikan loyalitas konsumen semakin 
tinggi. Seiring meningkatnya loyalitas konsumen dalam waktu lama maka penjualan perusahaan akan membaik dan perusahaan akan berjalan lancar. Secara teoretis perusahaan dikatakan mempunyai nilai baik jika kinerja perusahaan baik. Nilai perusahaan dapat tercermin dari harga sahamnya, apabila nilai sahamnya tinggi bisa dikatakan nilai perusahaannya juga baik karena tujuan utama perusahaan adalah meningkatkan nilai perusahaan melalui peningkatan kemakmuran pemilik atau pemegang saham (Rimba Kusumadilaga, 2010)

Corporate Social Responsibility saat ini bukan lagi bersifat sukarela namun telah bergeser menjadi kewajiban bagi beberapa perusahaan untuk menerapkannya, meskipun masih belum ada sanksi yang tegas terhadap perusahaan yang tidak melaksanakan CSR. Pesan moral penyelenggaraan CSR ini sebagaimana diamanatkan dalam UUPT yang disahkan pada 20 Juli 2007. Tanggung Jawab Sosial Perusahaan (CSR) telah dicantumkan dalam Pasal 74 UUPT yang berbunyi yaitu : 1) Perseroan yang menjalankan kegiatan usahanya dibidang dan/atau keterkaitan dengan sumber daya alam wajib melaksanakan Tanggung Jawab Sosial dan Lingkungan (TJSL). 2) Tanggung Jawab Sosial dan Lingkungan merupakan kewajiban Perseroan yang dianggarkan dan diperhitungkan sebagai biaya Perseroan yang pelaksanaannya dilakukan dengan memperhatikan kepatutan dan kewajaran. 3) Perseroan yang tidak melaksanakan kewajiban dikenai sanksi sesuai dengan ketentuan peraturan perundang-undangan.

Mendasarkan pada UUPT maka perusahaan khususnya perseroan terbatas yang bergerak dibidang dan atau terkait dengan sumber daya alam harus melaksanakan tanggung jawab sosial kepada masyarakat. Tanggung Jawab Sosial dan Lingkungan merupakan kewajiban perseroan yang dianggarkan dan diperhitungkan sebagai biaya perseroan yang pelaksanaannya dilakukan dengan memperhatikan kepatutan dan kewajaran. Ketentuan tersebut bertujuan untuk tetap menciptakan hubungan perseroan yang serasi, seimbang, dan sesuai dengan lingkungan, nilai, norma, dan budaya masyarakat setempat.

Undang-Undang RI No. 40 Tahun 2007 itulah yang menjadi dasar perusahaan dibidang pertambangan wajib melakukan pertanggung jawaban terkait kegiatan perusahaannya tentang Tanggung Jawab Sosial dan Lingkungan (TJSL). Dalam penelitian ini, yang dimaksudkan dengan perusahaan yang berkewajiban melaksanakan CSR adalah difokuskan pada Badan Usaha Milik Daerah (BUMD), meskipun tidak adanya pasal yang mengatur secara jelas tentang Corporate Social Responsibility bagi BUMD namun kata "usaha" pada frase "Badan Usaha Milik Daerah" telah memberikan arti unsur "perusahaan".

Terdapat pendapat yang menyatakan bahwa, " Ada sejumlah faktor yang mendorong dunia usaha melaksanakan aktifitas CSR sebagai bagian dari seluruh aktifitas perusahaan, walau bagi dunia usaha tertentu kegiatan CSR tidak diwajibkan, tetapi masih ada banyak faktor yang mendorong mereka untuk melakukan kegiatan CSR sehingga tidak jarang dijumpai adanya lembaga independen yang memberikan sertifikasi kepada dunia usaha yang telah melakukan berbagai aktifitas kepedulian sosial dan hal itu dianggap dapat menaikkan citra perusahaan sehingga memberikan stimulan bagi dunia usaha itu sendiri, selain itu banyak dunia usaha yang memperhitungkan bahwa kegiatan CSR yang dilakukan dapat menjadi bagian dan alat promosi pemasaran, dengan demikian mereka justru memasukkan kegiatan CSR ini sebagai bagian integral dan keseluruhan aktifitas bisnisnya". 
Undang-Undang Dasar NRI 1945, Pasal 33 ayat (2) dan ayat (3) menegaskan bahwa cabangcabang produksi yang penting bagi Negara dan yang menguasai hajat hidup orang banyak dikuasai oleh Negara, sedangkan bumi dan air serta kekayaan alam yang terkandung didalamnya dikuasai oleh Negara dan dipergunakan untuk sebesar-besarnya kemakmuran rakyat. Era otonomi daerah merupakan situasi dan kondisi bangkitnya kekuatan pemerintah daerah. Mendasarkan pada kondisi tersebut, perlu dilakukan review literatur untuk memberikan konsep dan kondisi pengelolaan BUMD berdasarkan referensi sebagai dasar pelaksanaan kajian selanjutnya. Dari review literatur mengenai Perusahaan Daerah ini dapat diketahui bahwa Perusahaan Daerah menurut UU Nomor 23 Tahun 2014 tentang Pemerintahan Daerah adalah badan usaha yang seluruh atau sebagian besar modalnya dimiliki oleh Daerah.

Hasil penelusuran terhadap peraturan perundang-undangan ternyata belum ditemukan Undang-undang tentang Badan Usaha Milik Daerah pengganti UU Nomor 5 Tahun 1962 tentang Perusahaan Daerah sebagai payung hukum Perusahaan Daerah. Kondisi ini sangat berbeda dengan Badan Usaha Milik Negara dimana telah memiliki payung hukum yaitu Undang-undang Nomor 19 Tahun 2003 tentang Badan Usaha Milik Negara. ${ }^{1}$ Tidak adanya payung hukum terhadap perusahaan daerah secara otomatis tidak terdapat dasar penerapan CSR bagi BUMD, sementara disisi lain akibat pelaksanaan operasional BUMD justru bersinggungan dengan kepentingan perlindungan lingkungan bagi masyarakat. Beberapa pokok permasalahan penting yang diajukan dalam penelitian ini dirumuskan sebagai berikut: 1) Apa dasar filosofis Corporate Social Responsibility ? 2) Bagaimanakah kedudukan hukum Corporate Social Responsibility dalam pengelolaan BUMD?

\section{METODOLOGI PENELITIAN}

Penelitian ini adalah tinjauan yuridis normatif, yaitu penelitian yang mengacu kepada normanorma hukum yang terdapat dalam peraturan perundang-undangan, sejarah, kasus dan putusan pengadilan sebagaimana sifat Ilmu Hukum yang "Sui Generis". Jenis data yang akan digunakan dalam penelitian ini adalah data primer yaitu data yang diperoleh melalui penelitian kepustakaan dan teknik pengumpulan dan inventarisasi peraturan perundangundangan, buku-buku, karya ilmiah, artikel-artikel yang ada hubungannya dengan masalah Corporate Social Responsibility, serta data yang diperoleh dari instansi atau lembaga tempat penelitian Peneliti yang telah tersedia. Data sekunder yaitu keterangan atau fakta yang diperoleh secara langsung dari sumber data atau melalui penelitian di lapangan dalam hal ini data yang diperoleh dari masyarakat dan BUMD.

Semua data primer yang bersifat menjelaskan bahan hukum primer berupa pendapat para ahli sarjana serta literatur-literatur yang relevan dengan objek penelitian. Bahan-bahan hukum yang digunakan dalam penelitian ini antara lain: 1) Bahan Hukum Primer yaitu bahan hukum yang mengikat yang terdiri dari peraturan perundang-undangan yang berlaku atau ketentuanketentuan yang berlaku. 2) Bahan Hukum Sekunder. Bahan hukum sekunder yang digunakan untuk mendukung bahan hukum primer, diantaranya yang berasal dari karya para sarjana, jurnal, data yang diperoleh dari instansi, serta buku-buku kepustakaan yang dapat dijadikan referensi yang dapat menunjang penelitian ini. 3) Bahan Hukum Tersier yaitu bahan hukum yang mengandung bahan hukum sekunder yang berasal dari kamus. Sumber data sekunder 
dalam penelitian ini adalah sejumlah data atau fakta yang diambil secara langsung dari sumber data di lapangan (Perusahaan Daerah dan masyarakat).

Kegiatan perolehan data dalam penelitian ini, dilakukan dengan cara library research, penelitian ini dilakukan untuk memperoleh data dari buku-buku, peraturan perundangundangan yang berlaku, putusan pengadilan, majalah ilmiah dan dokumen-dokumen lainnya yang berhubungan dengan pokok bahasan Corporate Social Responsibility. Analisis data dalam penelitian ini menggunakan pendekatan yang bersifat kualitatif. Data-data yang dianalisis dalam penelitian ini adalah bersifat menyeluruh dan merupakan satu kesatuan yang integral (holistic) tentang Corporate Social Responsibility dalam pengelolaan BUMD dan didukung oleh kepatuhan terhadap ketentuan-ketentuan yang berlaku (compliance).

\section{HASIL DAN PEMBAHASAN}

Corporate Social Responsibility adalah komitmen bisnis untuk berkontribusi pada pembangunan ekonomi berkelanjutan yang bekerja dengan karyawan dan reprsentatif mereka, masyarakat lokal dan masyarakat untuk bisnis dan baik untuk pembangunan. Perusahaan yang sedang menjalankan operasional bisnisnya memiliki keterkaitan dengan dengan masyarakat di lingkungannya, yang secara langsung dapat dipastikan merasakan dampak dari proses produksi perusahaan. Dampak yang dirasakan masyarakat sekitar tersebut pasti memiliki efek terhadap kehidupan mereka, yang sebelum kehadiran perusahaan di lingkungan tersebut, situasi dan kondisinya telah ada dan berjalan alami. Undang-Undang selalu mengandung norma hukum yang diidealkan (ideal norms) oleh suatu masyarakat ke arah mana cita-cita luhur kehidupan bermasyarakat dan bernegara hendak diarahkan. Cita-cita luhur yang terkandung dalam landasan filosofis hendaklah mencerminkan cita-cita filosofis yang dianut oleh bangsa Indonesia sendiri.

Landasan filosofis merupakan pertimbangan atau alasan yang menggambarkan bahwa peraturan yang dibentuk mempertimbangkan pandangan hidup, kesadaran, dan cita hukum yang meliputi suasana kebatinan serta falsafah bangsa Indonesia yang bersumber dari Pancasila dan pembukaan Undang-Undang Dasar Negara Republik Indonesia Tahun 1945. Dasar Negara Indonesia adalah Pancasila, telah memberikan panduan dalam Sila kelima Pancasila, keadilan sosial bagi seluruh rakyat Indonesia, memberi kewajiban kepada pemerintah untuk melaksanakan program-program yang bertujuan untuk mewujudkan keadilan sosial. Dalam pembukaan Undang-Undang Dasar Negara Republik Indonesia Tahun 1945 tercantum dengan jelas cita-cita bangsa Indonesia yang sekaligus merupakan tujuan nasional bangsa Indonesia. Cita-cita dan tujuan bangsa Indonesia tersebut adalah untuk melindungi segenap bangsa Indonesia dan seluruh tumpah darah Indonesia, memajukan kesejahteraan umum, mencerdaskan kehidupan bangsa dan ikut melaksanakan ketertiban dunia yang berdasarkan kemerdekaan, perdamaian abadi, dan keadilan sosial.

Badan Usaha Milik Daerah (BUMD) menurut UU Nomor 23 Tahun 2014 tentang Pemerintahan Daerah adalah badan usaha yang seluruh atau sebagian besar modalnya dimiliki oleh Daerah. Terdapat dua bentuk BUMD, yaitu: 1) Perusahaan Umum Daerah adalah BUMD yang seluruh modalnya dimiliki oleh satu Daerah dan tidak terbagi atas saham, dan 2) Perusahaan Perseroan Daerah adalah BUMD yang berbentuk perseroan terbatas yang modalnya terbagi dalam saham yang seluruhnya atau paling sedikit $51 \%$ (lima puluh satu persen) sahamnya dimiliki oleh satu Daerah. Mendasarkan pada peraturan perundangundangan ditemukan belum adanya Undang-undang tentang Badan Usaha Milik Daerah 
pengganti UU Nomor 5 Tahun 1962 tentang Perusahaan Daerah sebagai payung hukum BUMD. Kondisi ini sangat berbeda dengan Badan Usaha Milik Negara dimana telah memiliki payung hukum yaitu Undang-Undang Nomor 19 Tahun 2003 tentang Badan Usaha Milik Negara.

Konsep pengelolaan BUMD non persero (Perusahaan Daerah/Perusahaan Umum Daerah) dimungkinkan dengan model pengelolaan BUMD dengan sistem "swakelola mandiri". Konsep pengelolaan ini menggunakan sistem pengawasan ataupun pembinaan secara bertanggungjawab dan intensif. Pengelolaan BUMD dilakukan dengan pengawasan dan pembinaan secara langsung oleh pemangku kebijakan yang dilakukan oleh kepala daerah selaku pemegang otoritas tertinggi di pemerintah daerah. Kewenangan pemerintah daerah selaku pemegang otoritas dapat melakukan "intervensi kebijakan" dalam konteks yang positif terkait kinerja dari BUMD melalui dewan pengawas. Undang-Undang Nomor 23 Tahun 2014 tentang Pemerintah Daerah menyebutkan bahwa dalam pengelolaan BUMD salah satunya harus mengandung unsur tata kelola perusahaan yang baik. Namun demikian, peraturan pemerintah maupun peraturan lain yang mengatur lebih lanjut ketentuan mengenai tata kelola perusahaan yang baik dalam pengelolaan BUMD tersebut belum dikeluarkan. Sementara konsep pengelolaan BUMD persero (Perseroan Terbatas/Perusahan Perseroan Daerah), berdasarkan Permendagri Nomor 3 Tahun 1998 tentang Badan Hukum BUMD, menyatakan bahwa BUMD berbentuk perseroan terbatas tunduk pada UU Nomor 40 Tahun 2007 tentang Perseroan Terbatas dan peraturan pelaksanaannya.

Undang-Undang Nomor 40 Tahun 2007 tentang Perseroan Terbatas (PT) yang disahkan pada Tanggal 20 Juli 2007 mengatur kewajiban perusahaan untuk melakukan CSR. Kewajiban untuk melakukan tanggung jawab sosial tidak boleh dianggap sebagai beban bagi perusahaan, karena secara normative merupakan ketentuan yang wajib dilaksanakaan sebagai bentuk ketaatan terhdap peraturan. Pasal 74 UU No. 40/2007 merupakan aturan formal yang memperkenalkan konsep Tanggung Jawab Sosial Lingkungan (TJSL) yang di Indonesia pemakaian istilahnya sering dipertukarkan dengan Corporate Social Responsibility (CSR). Putusan Mahkamah Konstitusi Tanggal 15 April 2009 yang menolak permohonan uji materiil terhadap Pasal 74 ayat (1), (2) dan (3) UU No.40/ 2007 menguatkan bahwa CSR tetap merupakan kewajiban bagi perseroan yang menjalankan kegiatan usahanya di bidang dan/atau berkaitan dengan sumber daya alam. Amanat Pasal 74 ayat (1) bahwa CSR wajib hukumnya bagi perseroan yang menjalankan kegiatan usahanya di bidang dan/atau berkaitan dengan sumber daya alam. Ayat tersebut dikuatkan oleh ayat (2) yang menyatakan bahwa sebagai wujud konkret kewajiban CSR, perseroan harus memasukkan dana CSR didalam anggaran perseroan dan diperhitungkan sebagai biaya.

Peraturan Pemerintah No. 47 Tahun 2012 (PP No. 47/2012) yang diterbitkan Tanggal 4 April 2012, mengatur tentang Tanggung Jawab Sosial dan Lingkungan (TJSL) Perseroan Terbatas. Peraturan pemerintah ini merupakan turunan Undang-Undang No. 40 Tahun 2007 tentang Perseroan Terbatas (UU No. 40/2007). Pasal 74 ayat (3) UU No. 40/2007, ternyata bukan merupakan penguatan terhadap ayat (1) dan (2) yaitu 'Perseroan yang tidak melaksanakan kewajiban sebagaimana dimaksud pada ayat (1) dikenai sanksi sesuai dengan ketentuan peraturan perundang-undangan'. Substansi ayat (3) tidak menguatkan konsep yang mengatur tentang kewajiban perseroan menganggarkan dana CSR sebagai biaya sebagaimana yang diamanatkan oleh ayat (2). Ayat (3) ini mengatur tentang kewajiban lain, yaitu kewajiban perseroan untuk mematuhi aturan tentang tanggung jawab perseroan sebagaimana yang tertera didalam peraturan perundang-undangan tertentu. Peraturan Pemerintah No. 47/2012 yang 
diharapkan menjadi peraturan turunan yang menguatkan CSR pada UU No.40/2007, ternyata didalamnya tidak memuat kalimat yang "memerintahkan perseroan untuk memasukkan dana CSR dalam anggaran biaya perseroan, justru PP No. 47/2012 memberikan sepenuhnya otonomi penganggaran CSR itu kepada internal perseroan”.

\section{KESIMPULAN}

Corporate Social Responsibility merupakan tanggung jawab perusahaan terhadap masyarakat dan lingkungan sekitar sesuai amanat Pembukaan UUD NRI 1945 Pasal 33 ayat (1), CSR merupakan program-program pembangunan dalam masyarakat untuk mendatangkan keuntungan bagi perusahaan dan pemegang saham serta untuk menjalankan bisnisnya sesuai ketentuan hukum yang berlaku, karena perusahaan harus memiliki tanggung jawab moral, etika, dan filantropik. Corporate Social Responsibility dalam UU Nomor 40 Tahun 2007 tidak memiliki daya imperative, tidak mampu memberikan daya paksa terhadap perusahaan sehingga negara tidak memiliki kuasa untuk memaksa perseroan yang tidak memasukkan mata anggaran CSR di dalam daftar biayanya.

Berdasarkan hasil analisis pembahasan serta beberapa kesimpulan dan keterbatasan pada penelitian ini, beberapa hal yang dapat direkomendasikan, yaitu hendaknya penerapan CSR oleh perusahaan tidak didasarkan pada alasan normative peraturan perundang-undangan semata, namun lebih pada substansi CSR yang dapat meningkatkan value perusahaan. Pemerintah berkewajiban menerbitkan peraturan perundang-undangan yang memuat substansi lebih tegas atas kewajiban dan sanksi bagi perusahaan dalam mengimplementasikan CSR.

\section{DAFTAR PUSTAKA}

Adji, Indriyanto Seno, Korupsi Sistemik sebagai Kendala Penegakan Hukum di Indonesia, Jurnal Hukum Bisnis, Volume 24, No. 3, Tahun 2005.

Asshidqie, Jimly. (2006). Perihal Undang-Undang, Jakarta, Sekretariat Jenderal MK

Asyhadie, Zaeni. (2012). Hukum Bisnis : Prinsip dan Pelaksanaannya di Indonesia (Edisi Revisi), Jakarta : PT. RajaGrafindo Persada

Burton, Richard Simatupang. (2003). Aspek Huku dalam Bisnis, Jakarta : PT. Rineka Cipta.

Center, The Ary Suta. (2013). Strategis Management, Jakarta: The Ary Suta Center.

Chazawi, Adam. (2011). Hukum Pidana Materiil dan Formil Korupsi di Indonesia. Malang : Bayumedia Publishing.

Daryanto. (2012). Eksistensi BUMD dalam Otonomi Daerah, Majalah BUMN Link, 1:1

Dimyati, Khudzaifah dan Kelik Wardiono. (2014). Paradigma Rasional dalam Ilmu Hukum, Yogyakarta : GENTA Publishing.

Harold Arthur John Ford, Principles of Company Law, 5th Edition, Butterworths Pty. Limited, 1990

Hery. (2014). Controllership. Jakarta : PT. Gramedia Widiasarana Indonesia.

Hidayat, Syarif. (2007). Too Much Too Soon, Jakarta : RajaGrafindo Persada.

http://bersamadeddy.blogspot.co.id/2009/11/pengertian-dan-macam-macam-perusahaan.html http://lib.law.ugm.ac.id/ojs/index.php/pl/article/view/4766

http://www.hariansumutpos.com/2016/11/10

http://www.slideshare.net/budi22/kajian-bumd

https://hukumdankeadilan.wordpress.com/tag/uu-no-40-tahun-2007

Imam, Sentot Wahyono. (2010). Perilaku Organisasi. Yogyakarta : Graha Ilmu. 
Kamil, Ahmad dan Antonius Herusetya. Pengaruh Karakteristik Perusahaan Terhadap Luas Pengungkapan kegiatan Corporate Social Responsibility

Kumaat, Valery G. (2011). Internal Audit. Jakarta : Erlangga.

Kusumadilaga, Rimba. (2010). Pengaruh Corporate Social Responsibility Terhadap Nilai Perusahaan sebagai Variabel Moderating, Skripsi S1 FE Universitas Diponegoro.

Nasution, Bismar. (2009). Hukum Kegiatan Ekonomi I. Bandung: Books Terace \& Library.

Purwanto, Iwan. (2012). Manajemen Strategi, Bandung : CV. Yrama Widya.

Ridwan, Juniarso dan Acmad Sodik Sudrajat. (2009). Hukum Administrasi Negara dan Kebijakan Pelayanan Publik, Bandung : Nuansa.

Rosiana, Gusti Ayu Made Ervina, Gede Juliarsa, Maria M. Ratna Sari. (2013). Pengaruh Pengungkapan CSR Terhadap Nilai Perusahaan Dengan Profitabilitas Sebagai Variabel Pemoderasi, E-Jurnal Akuntansi Universitas Udayana, Denpasar

Setiyono. (2012). Teori-teori dan Alur Pikir Penerapan Pertanggungjawaban Pidana Korporasi. Malang : Bayu Media Publishing.

Sidhu, Inder. (2012). Cisco Doing Both, Yogyakarta : CV. ANDI Offset

Suharto, Edy. (2008) Kebijakan Sosial sebagai Kebiajakan Publik, Alfabeta

Taufiq, Muchamad. (2015). Eksistensi Good Corporate Governance pada Badan Usaha Milik Daerah Jurnal Relasi Volume XI, No.2 Tahun 2015.

Widjaja, Gunawan. (2004). Seri Aspek Hukum dalam Bisnis. Jakarta Timur : Prenada Media. Widjaya, IG.Rai. (2000). Hukum Perusahaan Perseroan Terbatas. Jakarta: Keasint Blanc. 